\title{
Rancang Bangun Game Platformer Daud VS Goliat Berbasis Android
}

\author{
Johan Tamin, I Made Agus Dwi Suarjaya, I Putu Agus Eka Pratama \\ Program Studi Teknologi Informasi, Fakultas Teknik, Universitas Udayana \\ Bukit Jimbaran, Bali, Indonesia, telp. (0361)701806 \\ email: johantamin@email.com, agussuarjaya@it.unud.ac.id, eka.pratama@unud.ac.id
}

\begin{abstract}
Abstrak
Cerita alkitab merupakan cerita mengenai tokoh alkitab bagi umat Yahudi dan Kristiani yang memiliki unsur sejarah. Cerita alkitab juga memiliki pesan moral yang baik dibalik cerita yang disampaikan. Salah satu cerita alkitab yang terkenal adalah kisah Daud dan Goliat. Kisah Daud melawan Goliat menceritakan kisah mengenai seorang pemuda gembala domba bernama Daud yang mampu mengalahkan prajurit raksasa bernama Goliat dikarenakan imannya yang kuat. Penelitian ini bertujuan mentransformasikan cerita alkitab yang umumnya dalam bentuk buku ke media aplikasi game berbasis Android sehingga lebih menarik dan dapat digunakan sebagai sarana mengajar pendidikan karakter untuk anak-anak sekolah minggu. Game Daud VS Goliat dikembangkan berbasis Android bergenre platformer. Metode pengukuran pengetahuan terhadap cerita dilakukan dengan model Pre-Experiment One Group Pretest-Posttest Design menggunakan media kuesioner yang diisi oleh 20 responden yaitu jemaat gereja. Hasil dari kuesioner yaitu jumlah responden yang mengetahui dan memahami isi cerita dan pesan moral dari cerita Daud dan Goliat sebelum memainkan game adalah $67,5 \%$ responden dan meningkat menjadi 99\% setelah memainkan game Daud VS Goliat.
\end{abstract}

Kata kunci: Cerita Alkitab, Daud dan Goliat, Android, Game, Platformer

\section{Abstract}

Bible story is a story about bible figures for Jews and Christians with historical elements. Bible story also have good moral message behind its story. One of the famous bible story is the story about David and Goliath. The story of David against Goliath tells about a young sheperd named David who was able to defeat a giant warrior named Goliat because of his strong faith. This study aims to transform bible story which commonly delivered from books into Android-based game applications to make it more interesting and can be used as a media for teaching character education for Sunday school children. The David VS Goliath game was developed with an Android-based and platformer genre. The method of measuring the knowledge of the story was done using the Pre-Experiment One Group Pretest-Posttest Design model using a questionnaire filled by 20 respondents which is the church congregation. The result of quiestionnaire is total of respondents who knows and understand the story and moral message from David and Goliath story before playing the game was $67,5 \%$ and increased into 99\% after playing David VS Goliath game.

Keywords: Bible Story, David and Goliath, Android, Game, Platformer

\section{Pendahuluan}

Alkitab merupakan sekumpulan kitab suci untuk umat Yahudi dan Kristiani dan ditulis pada waktu yang berlainan oleh para penulis (imam) yang berbeda di lokasi-lokasi berbeda. Alkitab diyakini sebagai hasil dari llham Allah dan digunakan sebagai pedoman untuk mengajar, menyatakan kesalahan, memperbaiki kelakuan, dan untuk mendidik orang dalam kebenaran [1]. Alkitab selain mengandung ajaran-ajaran secara tertulis, juga memiliki cerita-cerita mengenai tokoh alkitab yang digunakan sebagai pengajaran.

Cerita Alkitab banyak disampaikan dalam Alkitab khususnya dalam perjanjian lama. Cerita Alkitab memiliki unsur pesan moral yang sangat baik untuk anak-anak sekolah minggu. Cerita Alkitab biasanya disampaikan oleh guru-guru sekolah minggu dalam gereja. Salah satu cerita Alkitab yang terkenal adalah cerita mengenai Daud melawan Goliat. 
Penelitian lain yang mendukung pengenalan kisah Alkitab dengan media teknologi yaitu penelitian dengan judul "Motion Comic Kisah Penciptaan untuk Anak Sekolah Minggu" oleh Lauw [2], "Perancangan Buku Cerita Anak guna Membantu Pemahaman Alkitab" oleh Shirley [3], "Aplikasi Pengenalan Alkitab Interaktif untuk Anak Sekolah Minggu" oleh Ambat [4], "Pembuatan Cerita Alkitab tentang Yunus Berbasis Animasi Stop Motion" oleh Kasim [5], dan "Pembuatan Cerita Animasi 2D Interaktif tentang Kisah Alkitab Perjanjian Allah dengan Abraham untuk Anak Usia 6-9 Tahun" oleh Gustilah [6]. Penelitian oleh Lauw membahas tentang pembuatan motion comic untuk pengajaran anak sekolah minggu disertai dengan permainan dan fitur interaktif. Penelitian oleh Shirley membahas tentang pembuatan buku untuk membantu anak-anak sekolah minggu memahami isi cerita Alkitab. Penelitian oleh Ambat membahas tentang pembuatan media pembelajaran interaktif untuk anak-anak sekolah minggu. Penelitian oleh Kasim membahas tentang pembuatan aplikasi media pembelajaran mengenai cerita tentang Yunus berbasis animasi stop motion. Penelitian oleh Gustilah membahas tentang pembuatan aplikasi animasi 2D yang menceritakan kisah Abraham.

Penelitian lain yang mendukung pembuatan game edukasi dengan mengangkat cerita yang memiliki pesan moral yaitu penelitian dengan judul "Pemanfaatan Media Game I Gerantang untuk Melestarikan Cerita Rakyat Bali" oleh Purnawan [7], "Rancang Bangun Game Hanoman Heroes pada Platform Android" oleh Suryanata [8], "Rancang Bangun Game The Adventure of Timun Emas Berbasis Android" oleh Prayuda [9], "Rancang Bangun Game Edukasi Perjalanan Dang Hyang Nirartha di Bali" oleh Darmayanti [10], dan "Pengembangan Aplikasi Game Kisah Panji Sakti Berbasis Mobile" oleh Darma [11]. Penelitian oleh Purnawan membahas tentang pembuatan game dengan cerita I Gerantang pada berbasis Android. Penelitian oleh Suryanata membahas tentang pembuatan game dengan cerita pewayangan Hanoman berbasis Android. Penlitian oleh Prayuda membahas tentang pembuatan game dengan cerita rakyat Timun Emas berbasis Android. Penelitian oleh Darmayanti membahas tentang pembuatan game dengan cerita perjalanan pemuka agama Hindu Dang Hyang Nirartha berbasis Android. Penelitian oleh Darma membahas tentang pembuatan game dengan cerita rakyat Bali Panji Sakti berbasis Android.

Game Daud VS Goliat merupakan penelitian dengan konsep yang merupakan perpaduan dari konsep kedua jenis penelitian sebelumnya yang telah disampaikan yaitu pengenalan kisah Alkitab dengan media teknologi dan pembuatan game edukasi dengan mengangkat cerita yang memiliki pesan moral. Cerita yang diangkat berbeda dengan penelitian yang sebelumnya yaitu menggunakan cerita Alkitab Daud dan Goliat. Pemilihan media Android yang bersifat mobile sebagai platform game dikarenakan teknologi tersebut banyak digunakan oleh kalangan anak-anak dan sangat pesat perkembangannya [12]. Game dibuat menggunakan game engine Unity dengan bahasa pemrograman C\#. Pembuatan Game Daud VS Goliat diharapkan dapat meningkatkan minat anak-anak sekolah minggu dalam mempelajari cerita Alkitab dan amanat yang tersirat dalam cerita-cerita tersebut melalui media game yang disenangi oleh anak-anak.

\section{Metodologi Penelitian}

Game Daud VS Goliat dibuat untuk platform Android menggunakan Bahasa Pemrograman C\# pada engine Unity2D untuk memudahkan implementasi kode pada game. Tahapan pelaksanaan dalam perancangan game Daud VS Goliat yaitu Tahap Pendefinisian Kebutuhan Game, Tahap Perancangan Game, Tahap Implementasi, dan Tahap Pengujian. Tahap pertama yaitu pendefinisan kebutuhan game dilakukan dengan mengidentifikasi batasan masalah dan pengumpulan data untuk pembuatan game. Tahap kedua adalah perancangan game yang terdiri dari beberapa tahapan, yaitu perancangan karakter game, perancangan storyboard dan naskah, serta perancangan gameplay. Tahap terakhir adalah implementsai dan pengujian yang dilakukan dengan melakukan uji coba game terhadap kelompok jemaat gereja. Pengujian dinilai dengan memberikan pretest saat kelompok jemaat gereja belum memainkan game Daud VS Goliat dan posttest ketika selesai memainkan game, yang dilanjutkan dengan analisis hasil perbandingan pretest dan posttest. 


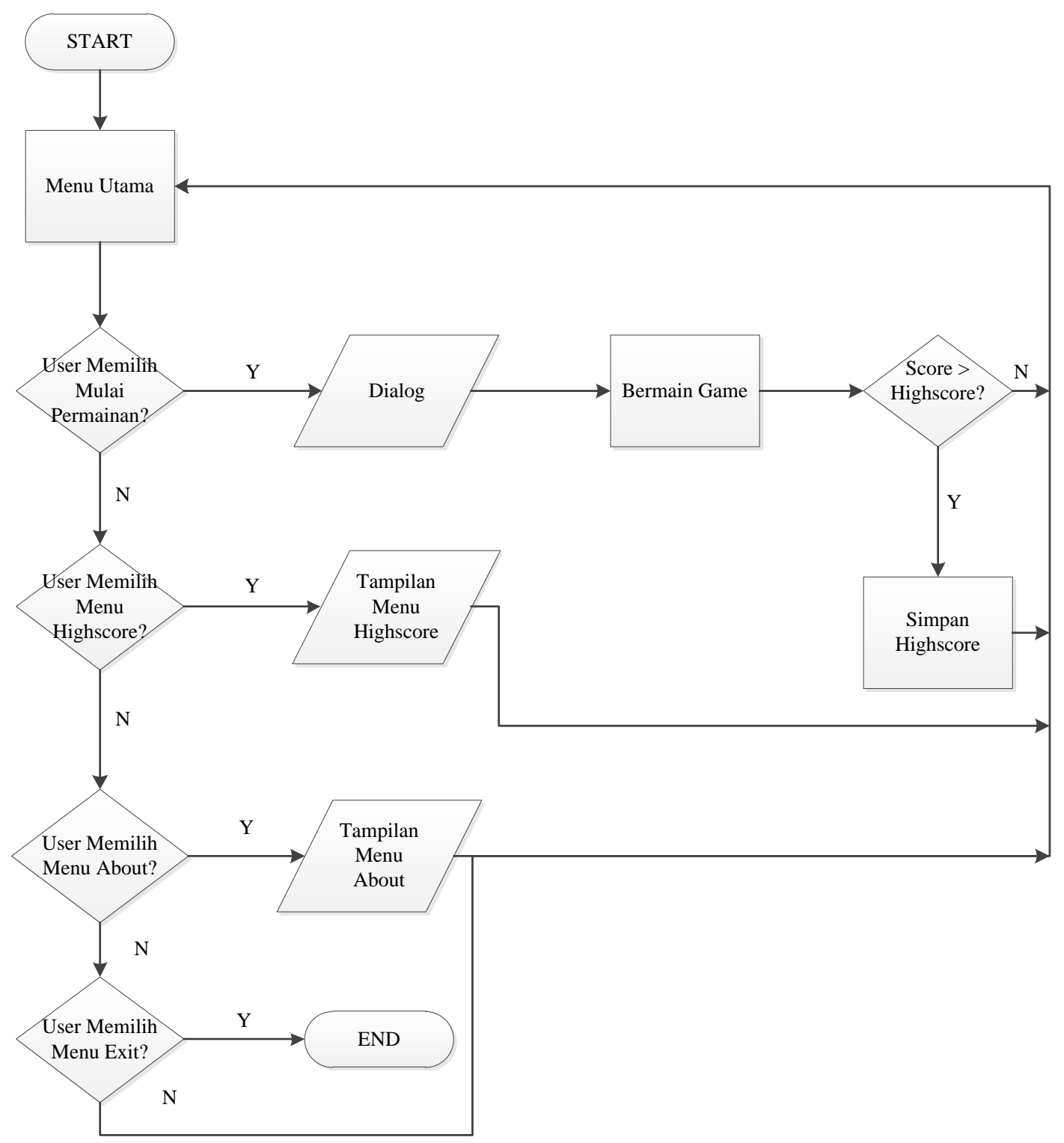

Gambar 1. Gambaran Umum Game Daud VS Goliat Berbasis Android

Gambar 1 merupakan gambaran umum dari game Daud VS Goliat. Game Daud VS Goliat terdiri dari empat menu yaitu, Mulai Main, Highscore, About, dan Keluar. Pemain dapat mengakses keempat menu tersebut dalam halaman menu utama game. Game akan dimulai dengan suguhan cerita dan dialog pada level pertama. Tampilan dialog game dilanjutkan dengan area level dimana pemain dapat mulai menggerakkan karakter pemain yaitu tokoh Daud dan mengalahkan semua musuh yang ada. Game memiliki mekanisme perhitungan score dimana pemain mendapatkan score apabila mampu mengalahkan musuh. Score pemain disimpan sebagai data highscore apabila score tersebut lebih tinggi dari data highscore yang ada saat permainan berakhir. 


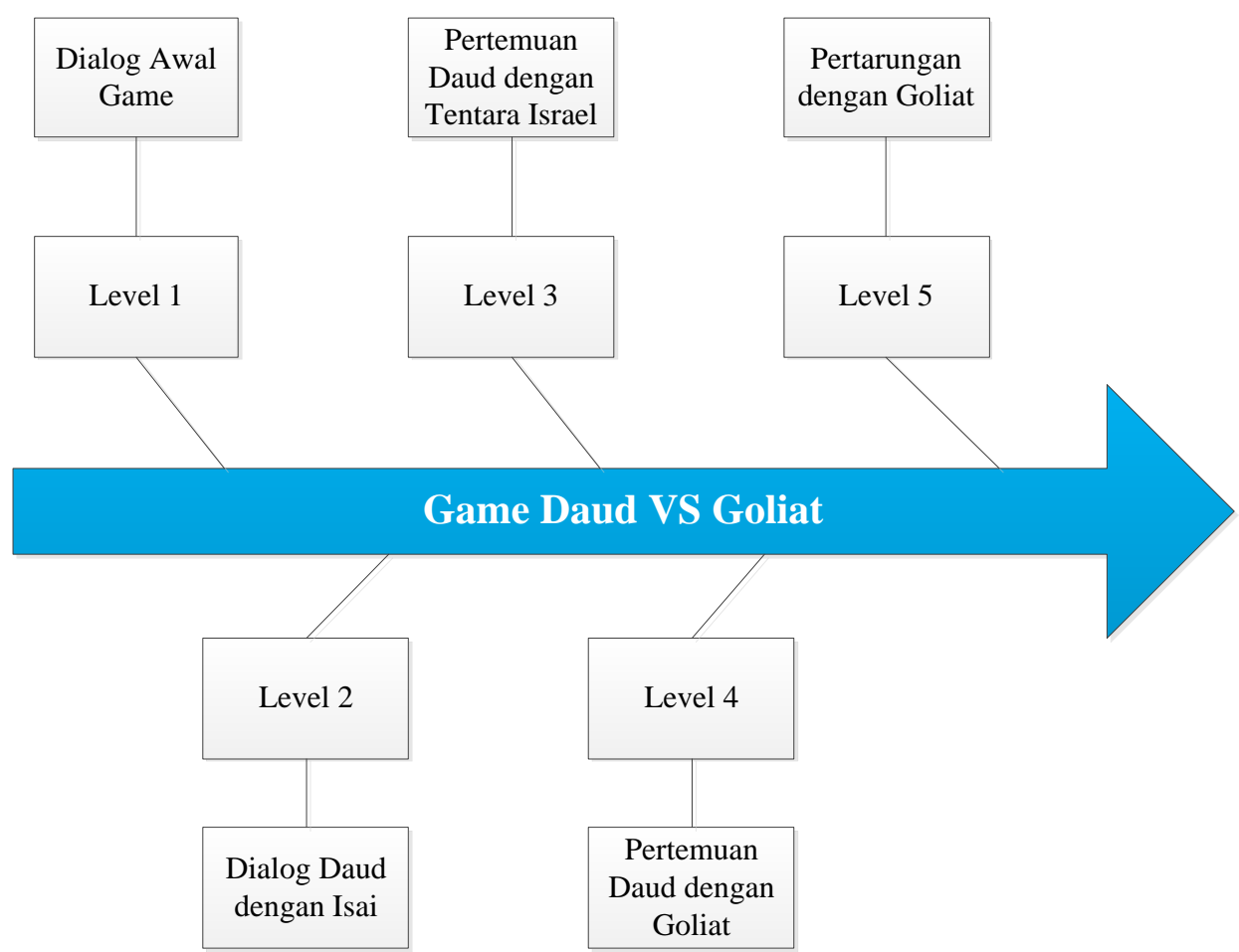

Gambar 2. Timeline Game Daud VS Goliat

Gambar 2 merupakan Rancangan alur waktu dari setiap cerita dalam Game Daud VS Goliat. Game memiliki lima level. Level pertama harus diselesaikan terlebih dahulu sebelum pemain dapat melanjutkan ke level berikutnya. Alur cerita Daud VS Goliat direpresentasikan dengan dialog yang ada pada setiap level. Setiap level memiliki bentuk area dan jumlah musuh yang berbeda. Pemain berperan sebagai tokoh Daud yang harus mengalahkan semua musuh sebelum dapat melanjutkan ke level berikutnya. Pemain melawan Boss dalam permainan yaitu Goliat ketika mencapai level terakhir permainan.

Metode pengujian untuk mengukur tingkat pengetahuan jemaat gereja terhadap isi cerita dan pesan moral dari cerita Daud dan Goliat melalui game Daud VS Goliat adalah PreExperimental yang memakai metode One Group Pretest-Posttest Design dengan demonstrasi game Daud VS Goliat sebagai Treatment. Metode pengumpulan data dilakukan dengan memberikan kuesioner untuk bagian pretest dan posttest kepada satu kelompok jemaat gereja sebagai responden. Pertanyaan pada kuesioner ditunjukkan pada Tabel 1.

Tabel 1. Pertanyaan kuesioner pretest dan posttest game Daud VS Goliat

\begin{tabular}{|c|c|c|}
\hline \multirow[b]{2}{*}{ No } & \multicolumn{2}{|c|}{ Pertanyaan } \\
\hline & Aspek Cerita & Aspek Moral \\
\hline 1 & $\begin{array}{l}\text { Anda memahami isi cerita dari Kisah } \\
\text { Daud melawan Goliat. }\end{array}$ & $\begin{array}{l}\text { Terdapat pesan moral yang terkandung } \\
\text { dalam Kisah Daud melawan Goliat. }\end{array}$ \\
\hline 2 & Daud merupakan tokoh yang baik. & $\begin{array}{l}\text { Adanya pesan moral "Taat kepada orang } \\
\text { tua." }\end{array}$ \\
\hline 3 & Goliat merupakan tokoh yang jahat & $\begin{array}{l}\text { Adanya pesan moral "Percaya kepada } \\
\text { Tuhan agar selalu dilindungi." }\end{array}$ \\
\hline 4 & $\begin{array}{l}\text { Daud merupakan seorang gembala } \\
\text { domba. }\end{array}$ & $\begin{array}{l}\text { Adanya pesan moral "Percaya kepada } \\
\text { Tuhan maka segl sesuatu tidak ada yang } \\
\text { mustahil." }\end{array}$ \\
\hline 5 & $\begin{array}{l}\text { Daud dimintai ayahnya } \\
\text { membawakan makanan kepada } \\
\text { kakaknya. }\end{array}$ & $\begin{array}{l}\text { Adanya pesan moral "Kebaikan akan } \\
\text { selalu menang melawan kejahatan." }\end{array}$ \\
\hline 6 & $\begin{array}{l}\text { Daud mencari ketiga kakaknya saat } \\
\text { sampai ke kemah pertempuran }\end{array}$ & \\
\hline
\end{tabular}




\begin{tabular}{clll}
\hline \multirow{2}{*}{ No } & \multicolumn{1}{c}{ Pertanyaan } & Aspek Moral \\
\cline { 2 - 3 } & Aspek Cerita & \\
\hline 7 & $\begin{array}{l}\text { Goliat menantang pasukan Israel dalam } \\
\text { pertempuran satu lawan satu. }\end{array}$ \\
\hline 8 & $\begin{array}{l}\text { Daud menantang Goliat dalam } \\
\text { pertempuran satu lawan satu. }\end{array}$ \\
\hline 9 & $\begin{array}{l}\text { Daud meminta izin raja Saul untuk } \\
\text { melawan Goliat. }\end{array}$ \\
\hline 10 & Daud menang melawan Goliat. & \\
\hline
\end{tabular}

Penetapan nilai atau skor yang digunakan pada kuesioner menggunakan skala Likert, yaitu sebagai berikut. SS, yaitu indikator penilaian yang menunjukkan respon sangat setuju. S, yaitu indikator penilaian yang menunjukkan respon setuju. TS, yaitu indikator penilaian yang menunjukkan respon tidak setuju. STS, yaitu indikator penilaian yang menunjukkan respon tidak setuju. Skor SS dan S menandakan responden mengetahui isi cerita atau memahami pesan moral dalam game. Skor TS dan STS menandakan responden tidak mengetahui isi cerita atau tidak memahami pesan moral dalam game.

\section{Kajian Pustaka}

\subsection{Cerita Daud dan Goliat}

Daud dan Goliat merupakan salah satu kisah Alkitab yang cukup terkenal. Kisah Daud dan Goliat menceritakan tentang pertempuran antara tentara Israel melawan tentara Filistin. Cerita bermula ketika ayah Daud yang bernama Isai meminta Daud untuk membawakan makanan kepada ketiga kakaknya yang saat itu menjadi tentara Israel untuk berperang melawan tentara Filistin. Daud merupakan remaja yang bekerja sebagai gembala domba. Daud berlari ke barisan perang untuk mencari kakak-kakaknya ketika sampai ke perkemahan perang tentara Israel.

Goliat yang merupakan prajurit terbesar dari tentara Filistin menantang semua tentara Israel untuk melawan dia, namun semua prajurit tentara Israel takut dikarenakan ukuran badan Goliat yang besar melebihi manusia biasa. Daud tidak tinggal diam dan menjawab tantangan Goliat. Daud diantar kepada Raja Saul yang saat itu memimpin pasukan tentara Israel. Raja Saul menganggap remeh permintaan Daud untuk melawan Goliat dikarenakan Daud masih sangat muda, namun setelah Daud menceritakan kisah dia sebagai gembala yang selalu melindungi kawanan dombanya dari ancaman seperti singa dan beruang, Raja Saul akhirnya mengijinkan Daud untuk melawan Goliat.

Daud yang hanya memiliki umbai dan batu akhirnya berhadapan dengan Goliat. Daud berlari ke arah Goliat lalu mengambil sebuah batu dari kantongnya dan menaruhnya dalam umbannya. Daud melontarkannya dengan sekuat tenaga hingga batu itu melayang dan langsung mengenai kepala Goliat. Goliat akhirnya terjatuh mati dengan batu yang tertanam di kepalanya dan tentara Filistin lari ketakutan. Tentara Israel mengejar mereka dan menyatakan kemenangan dalam pertempuran.

\subsection{Android}

Android merupakan sistem operasi yang digunakan untuk smartphone berbasis Linux. Android memiliki performa tingkat tinggi yang setara dengan komputer yang memungkinkan pengguna untuk tidak hanya menggunakan fitur panggilan dan SMS, tetapi juga menggunakan fitur-fitur canggih seperti koneksi internet. Android menyediakan layanan open source yang dapat digunakan pengembang untuk menciptakan aplikasi secara bebas [13]. Open source memungkinkan pengembang untuk menyediakan aplikasi mereka kepada orang banyak secara gratis dan memotivasi pengguna lain untuk dapat melakukan kontribusi dan memberikan manfaat kepada orang lain [14]. Android digunakan sebagai media pengembangan aplikasi karena memberikan kemudahan untuk pengguna dalam mengakses informasi melalui smartphone mereka [15]. 


\subsection{Mobile Game}

Mobile Game merupakan jenis game yang didesain untuk dapat dijalankan pada perangkat mobile seperti smartphone dan tablet PC. Mobile Game dibuat dengan tujuan untuk dapat dimainkan oleh pemain dimana saja dan kapan saja melalui perangkat mobile [16]. Mobile Game pada saat ini telah dibuat di berbagai macam platform mobile khususnya Android. Beberapa contoh penelitian yang membahas pembuatan game menggunakan media Android adalah "Augmented Reality for Chemical Elements : PeriodikAR" oleh Sudana [17] dan "Rancang Bangun Game Tapel Bali pada Platform Android" oleh Putra [18]. Penelitian oleh Sudana membahas tentang penggunaan teknologi Augmented Reality untuk penyampaian Tabel Periodik Unsur Kimia dengan menggunakan perangkat mobile Android, sementara penelitian oleh Putra membahas tentang pembuatan game pembuatan Topeng Bali dengan menggunakan perangkat Android.

\subsection{Platform Game}

Platform Game atau platformer merupakan salah satu genre dari game dan merupakan subgenre dari action game dan puzzle game. Konsep permainan dari platform game adalah pemain menggerakkan suatu karakter atau avatar permainan dan menuntun mereka melewati berbagai jenis bentuk platform atau menghindari berbagai jenis rintangan sesuai dengan desain level permainan. Level permainan dalam platform game memiliki suatu misi yang harus dilakukan pemain untuk menyelesaikan permainan seperti mengalahkan semua musuh atau menggerakkan karakter permainan hingga mencapai finish [19].

\section{Hasil dan Pembahasan}

4.1 Tampilan Game Daud VS Goliat

Bab hasil dan pembahasan membahas mengenai tampilan Game Daud VS Goliat pada scene-scene utama dan alur permainan atau gameplay yang dimiliki.

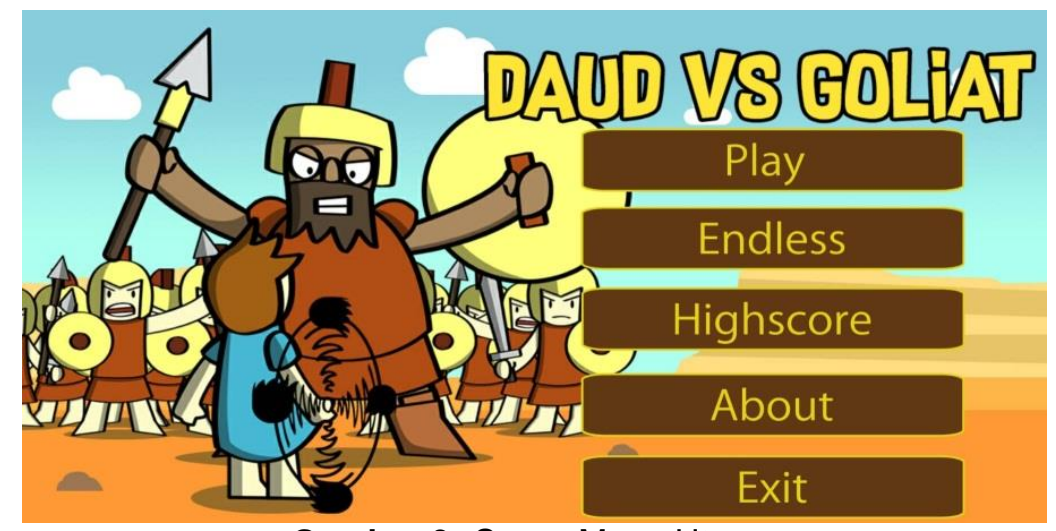

Gambar 3. Scene Menu Utama

Gambar 3 merupakan tampilan menu utama pada game Daud VS Goliat. Tombol Play digunakan untuk memulai permainan. Tombol Highscore digunakan untuk mengakses halaman highscore. Tombol About digunakan untuk mengakses halaman mengenai info game serta pembuatnya. Tombol Exit digunakan untuk keluar dari permainan. 


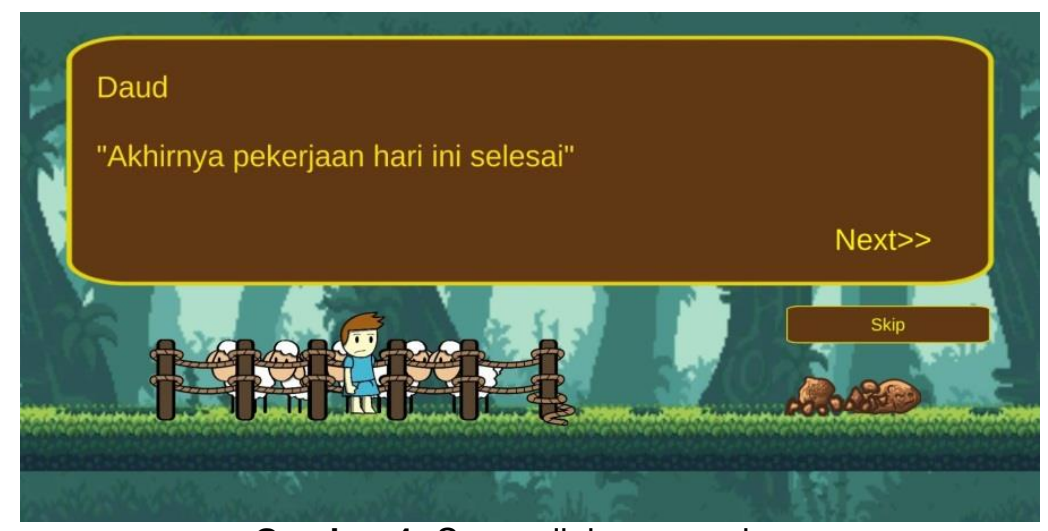

Gambar 4. Scene dialog permainan

Gambar 4 merupakan tampilan scene dialog pada game Daud VS Goliat. Nama Pembicara merupakan nama dari tokoh yang sedang berbicara. Panel Dialog merupakan isi dari pembicaraan dari dari tokoh game maupun narasi dari cerita dalam game. Pemain dapat menekan Panel Dialog untuk melanjutkan narasi atau dialog yang sedang berlangsung.

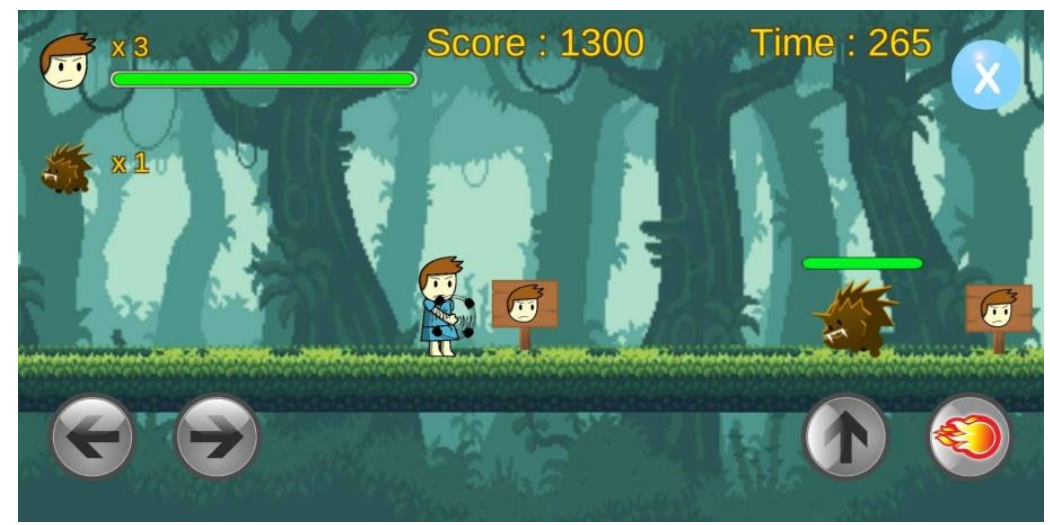

Gambar 5. Scene Permainan

Gambar 5 merupakan tampilan scene permainan pada game Daud VS Goliat. Tampilan permainan terdiri dari Bar Darah Pemain, Jumlah Nyawa Pemain, Jumlah Score, Sisa Waktu, Tombol Pause, Jumlah Musuh, Tombol Gerak, Tombol Lompat, dan Tombol Tembak. Bar Darah Pemain merupakan tampilan bar untuk sisa darah pemain, apabila darah pemain habis maka nyawa pemain berkurang. Jumlah Nyawa Pemain merupakan tampilan jumlah nyawa yang dimiliki pemain, apabila nyawa pemain habis maka permainan berakhir. Jumlah Score merupakan tampilan jumlah score yang sudah dicapai pemain. Sisa Waktu merupakan tampilan sisa waktu permainan, permainan berakhir apabila waktu permainan habis. Tombol Pause digunakan untuk menghentikan permainan secara sementara (pause). Jumlah Musuh merupakan tampilan sisa jumlah musuh dalam level permainan, pemain harus mengalahkan semua musuh sebelum pemain dapat melanjutkan permainan ke level berikutnya. Tombol Gerak digunakan untuk menggerakkan karakter pemain kearah kiri maupun kanan. Tombol Lompat digunakan untuk melakukan gerakan lompatan pada karakter pemain. Tombol Tembak digunakan untuk melakukan aksi serangan yaitu penembakan proyektil pada karakter pemain.

\subsection{Hasil Pengukuran Pengetahuan Jemaat Gereja tentang Cerita Daud dan Goliat melalui Game Daud VS Goliat}

Pengukuran pengetahuan tentang Cerita Daud dan Goliat melalui Game Daud VS Goliat dilakukan oleh Kelompok Jemaat Gereja dari Gereja Bethesda yang berjumlah 20 responden. Pretest dilakukan terlebih dahulu kepada kelompok jemaat gereja, kemudian diberikan demonstrasi game Daud VS Goliat, dan terakhir dilakukan posttest kepada kelompok jemaat gereja. Hasil pretest dan posttest akan dibandingkan untuk melihat adanya peningkatan 
pengetahuan jemaat gereja terhadap detail cerita dan pesan moral yang terkandung dalam Cerita Daud dan Goliat.

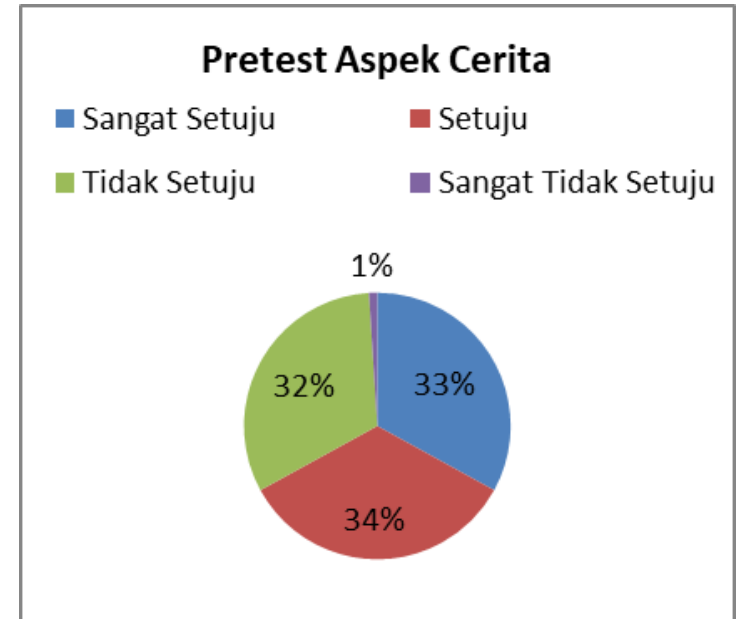

(a)

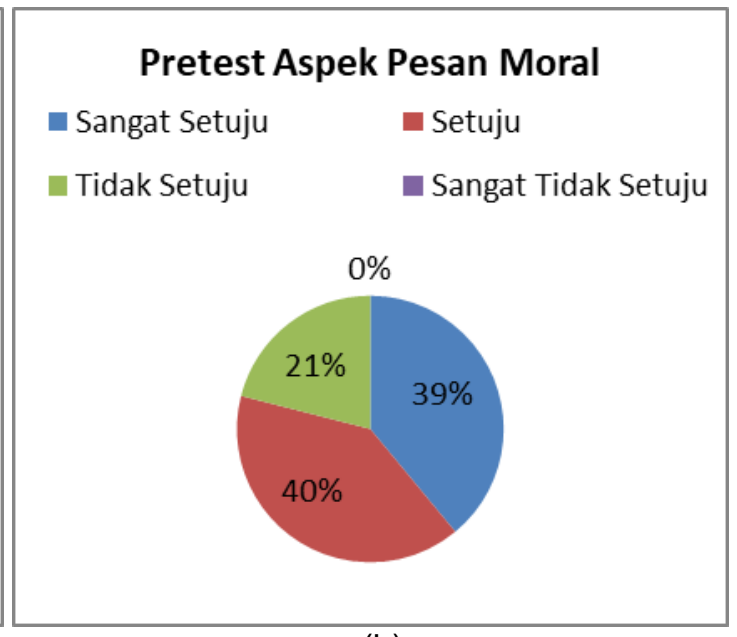

(b)

Gambar 6. Diagram Persentase Hasil Pretest: (a) Pretest Aspek Cerita; (b) Pretest Aspek Pesan Moral

Gambar 6(a) merupakan hasil pretest untuk aspek cerita game Daud VS Goliat. Respon sangat tidak setuju diberikan oleh responden sebesar $1 \%$, respon tidak setuju diberikan oleh responden sebesar 31,5\%, respon setuju diberikan oleh responden sebesar $34,5 \%$, dan respon sangat setuju diberikan oleh responden sebesar 33\%. Hasil pretest menunjukkan bahwa $67,5 \%$ responden dari kelompok jemaat gereja sudah mengetahui isi cerita dari Cerita Daud dan Goliat, sementara $32,5 \%$ responden belum mengetahui isi cerita dari Cerita Daud dan Goliat.

Gambar 6(b) merupakan hasil pretest untuk aspek pesan moral game Daud VS Goliat. Respon sangat tidak setuju diberikan oleh responden sebesar $0 \%$, respon tidak setuju diberikan oleh responden sebesar $21 \%$, respon setuju diberikan oleh responden sebesar $40 \%$, dan respon sangat setuju diberikan oleh responden sebesar $39 \%$. Hasil pretest menunjukkan bahwa $79 \%$ responden dari kelompok jemaat gereja sudah memahami pesan moral dari Cerita Daud dan Goliat, sementara 21\% responden belum memahami pesan moral dari Cerita Daud dan Goliat.

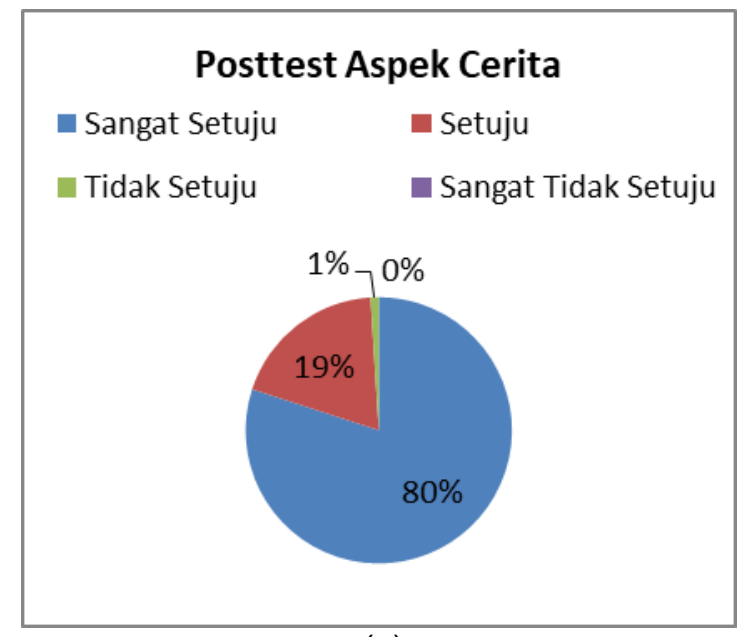

(a)

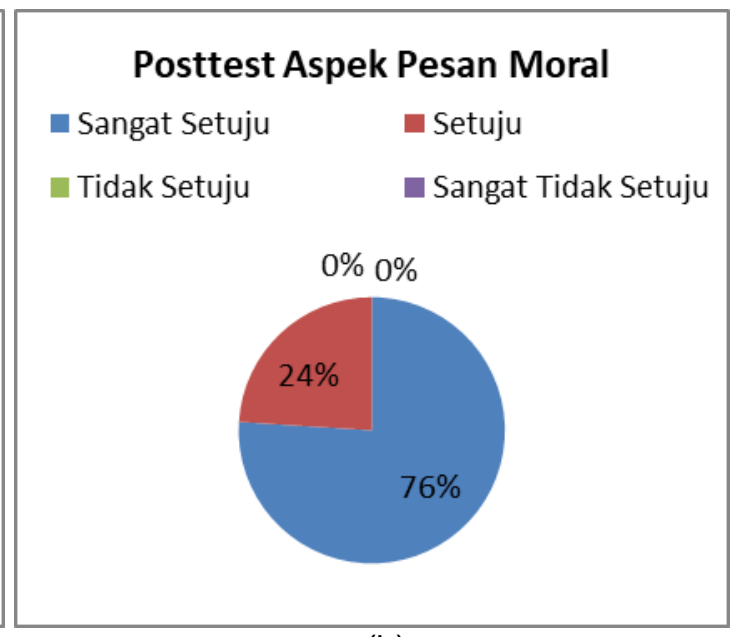

(b)

Gambar 7. Diagram Persentase Hasil Posttest: (a) Posttest Aspek Cerita; (b) Posttest Aspek Pesan Moral 
Gambar 7(a) merupakan hasil posttest untuk aspek cerita game Daud VS Goliat. Respon sangat tidak setuju diberikan oleh responden sebesar $0 \%$, respon tidak setuju diberikan oleh responden sebesar $1 \%$, respon setuju diberikan oleh responden sebesar $19 \%$, dan respon sangat setuju diberikan oleh responden sebesar $80 \%$. Hasil posttest menunjukkan bahwa setelah diberikan demonstrasi game Daud VS Goliat, total responden kelompok jemaat gereja yang mengetahui isi cerita dari Cerita Daud dan Goliat sebanyak 67,5\% berubah menjadi $99 \%$.

Gambar 7(b) merupakan hasil posttest untuk aspek pesan moral game Daud VS Goliat. Respon sangat tidak setuju dan tidak setuju diberikan oleh responden sebesar $0 \%$, respon setuju diberikan oleh responden sebesar $24 \%$, dan respon sangat setuju diberikan oleh responden sebesar $76 \%$. Hasil posttest menunjukkan bahwa setelah diberikan demonstrasi game Daud VS Goliat, total responden kelompok jemaat gereja yang memahami pesan moral dari Cerita Daud dan Goliat sebanyak 79\% berubah menjadi 100\%.

\begin{tabular}{|c|c|c|c|c|}
\hline \multirow[t]{2}{*}{ No } & \multirow[t]{2}{*}{ Variabel Penilaian } & \multirow[t]{2}{*}{ Kriteria } & \multicolumn{2}{|c|}{ Hasil } \\
\hline & & & Pretest & Posttest \\
\hline \multirow[t]{4}{*}{1} & Aspek Cerita & Sangat Setuju & $33 \%$ & $80 \%$ \\
\hline & & Setuju & $34.5 \%$ & $19 \%$ \\
\hline & & Tidak Setuju & $31.5 \%$ & $1 \%$ \\
\hline & & Sangat Tidak Setuju & $1 \%$ & $0 \%$ \\
\hline \multirow[t]{4}{*}{2} & Aspek Pesan Moral & Sangat Setuju & $39 \%$ & $76 \%$ \\
\hline & & Setuju & $40 \%$ & $24 \%$ \\
\hline & & Tidak Setuju & $21 \%$ & $0 \%$ \\
\hline & & Sangat Tidak Setuju & $0 \%$ & $0 \%$ \\
\hline
\end{tabular}

Tabel 2 menunjukkan bahwa pada aspek cerita, kriteria sangat setuju bernilai $33 \%$ dan setuju bernilai $34,5 \%$ pada pretest, kemudian berubah menjadi $80 \%$ sangat setuju dan $19 \%$ setuju pada posttest. Kriteria tidak setuju bernilai $31,5 \%$ dan sangat tidak setuju bernilai $1 \%$ pada pretest, kemudian berubah menjadi $1 \%$ tidak setuju dan $0 \%$ sangat tidak setuju pada posttest. Hasil pretest dan posttest membuktikan bahwa sebelum kelompok jemaat gereja memainkan game Daud VS Goliat, terdapat $67,5 \%$ responden yang mengetahui isi cerita dari Cerita Daud dan Goliat, kemudian setelah memainkan game Daud VS Goliat, jumlah responden dari kelompok jemaat gereja yang mengetahui isi cerita dari Cerita Daud dan Goliat berubah menjadi $99 \%$.

Hasil kuesioner pada aspek moral, kriteria sangat setuju bernilai $39 \%$ dan setuju bernilai $40 \%$ pada pretest, kemudian berubah menjadi $76 \%$ sangat setuju dan $24 \%$ setuju pada posttest. Kriteria tidak setuju bernilai $21 \%$ dan sangat tidak setuju bernilai $0 \%$ pada pretest, kemudian berubah menjadi $0 \%$ tidak setuju dan $0 \%$ sangat tidak setuju pada posttest. Hasil pretest dan posttest membuktikan bahwa sebelum kelompok jemaat gereja memainkan game Daud VS Goliat, terdapat $79 \%$ responden yang memahami pesan moral dari Cerita Daud dan Goliat, kemudian setelah memainkan game Daud VS Goliat, jumlah responden dari kelompok jemaat gereja yang memahami pesan moral dari Cerita Daud dan Goliat berubah menjadi 100\%.

\section{Kesimpulan}

Game Daud VS Goliat yang dihasilkan dari penelitian ini merupakan game yang memiliki genre platformer dengan mengangkat cerita tokoh Alkitab Daud saat melawan Goliat. Game Daud VS Goliat dibuat sebagai media pembelajaran yang lebih menarik terutama untuk kalangan anak-anak sekolah minggu dibandingkan dengan penggunaan buku sebagai media penyampaian cerita. Evaluasi peranan game Daud VS Goliat sebagai media pembelajaran dan penyampaian pesan moral menggunakan media kuesioner yang dibagikan kepada 20 responden yaitu kelompok jemaat gereja. Hasil kuesioner yang diperoleh yaitu responden sebanyak $67,5 \%$ telah mengetahui isi cerita dan $79 \%$ responden telah memahami pesan moral dari cerita sebelum memainkan game Daud VS Goliat, dan jumlah responden meningkat menjadi $99 \%$ untuk yang mengetahui cerita dan 100\% untuk yang memahami pesan moral dari cerita setelah memainkan game Daud VS Goliat. 


\section{Daftar Pustaka}

[1] B. D. Nainggolan, "Interpretasi : Dunia Mepertanyakan Apakah Alkitab Benar Diilhamkan Allah?," Jurnal Koinonia, vol. 9, no. 1, pp. 13-21, 2015.

[2] A. Lauw, "Motion Comic Kisah Penciptaan untuk anak sekolah minggu," Calyptra: Jurnal IImiah Mahasiswa Universitas Surabaya, vol. 3, no. 1, pp. 1-6, 2014.

[3] Shirley and R. Iswanto, "Perancangan Buku Cerita Anak Guna Membantu Pemahaman Alkitab," Jurnal VCD (Universitas Ciputra), vol. 7, no. 2, pp. 35-42, 2017.

[4] M. P. Ambat, S. R. Sentinuwo, and B. A. Sugiarso, "Aplikasi Pengenalan Alkitab Interaktif untuk Anak Sekolah Minggu," E-Journal Teknik Informatika (Universitas Sam Ratulangi), vol. 11, no. 1, 2017.

[5] M. Kasim, "Pembuatan Cerita Alkitab tentang Yunus Berbasis Animasi Stop Motion," Calyptra: Jurnal IImiah Mahasiswa Universitas Surabaya, vol. 4, no. 1, pp. 1-11, 2015.

[6] N. W. Gustilah, "Pembuatan Cerita Animasi 2D Interaktif Tentang Kisah Alkitab Perjanjian Allah dengan Abraham untuk Anak Usia 6-9 Tahun," Calyptra: Jurnal IImiah Mahasiswa Universitas Surabaya, vol. 4, no. 1, pp. 1-6, 2015.

[7] P. N. Purnawan, A. A. K. A. C. Wiranatha, and I. A. D. Suarjaya, "Pemanfaatan Media Game I Gerantang untuk Melestarikan Cerita Rakyat Bali," Jurnal IImiah Merpati Universitas Udayana, vol. 6, no. 2, pp. 127-135, 2018.

[8] I. M. Suryanata, I. P. A. Bayupati, and K. S. Wibawa, "Rancang Bangun Game Hanoman Heroes pada Platform Android," Jurnal IImiah Merpati Universitas Udayana, vol. 4, no. 2, pp. 135-142, 2016.

[9] I. M. M. Prayuda, I. P. A. Bayupati, and A. A. K. A. C. Wiranatha, "Rancang Bangun Game the Adventure of Timun Emas Berbasis Android," Jurnal IImiah Merpati Universitas Udayana, vol. 4, no. 3, pp. 214-224, 2016.

[10] N. L. C. Darmayanti, I. K. A. Purnawan, and P. W. Buana, "Rancang Bangun Game Edukasi Perjalanan Dang Hyang Nirartha di Bali," Jurnal IImiah Merpati Universitas Udayana, vol. 5, no. 2, pp. 23-33, 2017.

[11] N. T. A. Darma, I. K. R. Arthana, and I. M. Putrama, "Pengembangan Aplikasi Game Kisah Panji Sakti Berbasis Mobile," Jurnal Nasional Pendidikan Teknik Informatika (JANAPATI), vol. 6, no. 3, pp. 283-294, 2017.

[12] I. D. G. A. Pandawana and D. P. Y. Ardiana, "Aplikasi Game Cerita Rakyat Bali Sebagai Sarana Pendidikan Karakter Anak Berbasis Mobile," Jurnal Imiah Teknologi Informasi Lontar Komputer, vol. 8, no. 3, pp. 208-218, 2018.

[13] I. P. P. Andika, I. P. A. Bayupati, and N. K. A. Wirdiani, "Rancang Bangun Aplikasi Pendeteksi Tipe dan Nilai Resistor Berbasis Android," Jurnal Imiah Teknologi Informasi Lontar Komputer, vol. 6, no. 1, pp. 61-72, 2015.

[14] T. C. Rante, A. S. M. Lumenta, and B. A. Sugiarso, "Pemanfaatan Aplikasi Open Source untuk Puskesmas (Studi Kasus Puskesmas Kota Minahasa)," E-Journal Teknik Elektro dan Komputer (Universitas Sam Ratulangi), vol. 4, no. 4, pp. 57-64, 2015.

[15] A. A. K. O. Sudana, I. W. G. M. Kepakisan, and N. K. D. Rusjayanthi, "Implementation of Tree Structure and Recursive Algorithm for Balinese Traditional Snack Recipe on Android Based Application," International Journal of Interactive Mobile Technologies (iJIM), vol. 10, no. 4, pp. 43-47, 2016.

[16] David, "Perancangan Game Mobile Android Bergenre Horror," CoglTo Smart Journal, vol. 2, no. 2, pp. 167-179, 2016.

[17] A. A. K. O. Sudana, A. Setiawan, and I. P. A. E. Pratama, "Augmented Reality for Chemical Elements: PeriodikAR," Journal of Theoretical and Applied Information Technology (JATIT), vol. 90, no. 1, pp. 88-92, 2016.

[18] I. D. M. Y. A. Putra, A. A. K. A. C. Wiranatha, and P. W. Buana, "Rancang Bangun Game Tapel Bali pada Platform Android," Jurnal Imiah Teknologi Informasi Lontar Komputer, vol. 6, no. 1, pp. 1-12, 2015.

[19] T. Bhosale, S. Kulkarni, and S. N. Patankar, "2D Platformer Game In Unity Engine," International Research Journal of Engineering and Technology (IRJET), vol. 5, no. 4, pp. 3021-3024, 2018. 